\author{
총체맥류 주요품종의 봄 파종에 따른 생육, 수량 및 \\ 사료가치 비교 \\ 주정일 $\cdot$ 이동희 $\cdot$ 성열규 $\cdot$ 한옥규 $^{1} \cdot$ 송태화 $^{1} \cdot$ 이광원 $^{1} \cdot$ 김창호 $^{2}$
}

\title{
Comparisons of Growth, Yield and Feed Quality at Spring Sowing among Five Winter Cereals for Whole-crop Silage Use
} Jung II Ju, Dong Hee Lee, Yeul Gue Seong, Ouk Kyu Han¹, Tae Hwa Song ${ }^{1}$, Kwang Won Lee ${ }^{2}$ and Chang Ho Kim²

\begin{abstract}
Few spring sowing have been conducted on winter cereal crops for whole-crop silage use. Experiments were conducted during 2007 and 2008 at the Chungnam Agricultural Research \& Extension Services. The objectives of this study were compared the spring sowing with the optimum season's sowing on growth, yield and feed quality in five winter cereal crops. The treatments consisted of 5 winter cereal crops, Youngyang (Barley, Spring habit I ), Keumkang (Wheat, Spring habit II), Gogu(Rye, Spring habit estimated III), Shinyoung (Triticale, Spring habit estimated III), Samhan(Oat, Spring habit estimated II), and 3 planting dates, 18 October (optimum season's sowing), 23 February and 10 March in spring. Heading days as affected by spring sowing compared to optimum season sowing were delayed by $16 \sim 20$ days in barley, wheat, rye and triticale, and 9 days in oat. The clipping dates at the optimal harvesting stage of each crop for round-baled silage in spring sowing was 8 June (yellow ripe stage) in barley, 25 May (10 days after heading) in rye, and 17 June in wheat (yellow ripe stage), triticale (milky stage) and oat (milky stage). The accumulative temperature from emergence to heading was significantly decreased as affected by spring sowing compared to optimum season's sowing, but that of sowing to emergence and that of heading to maturing was similar. The rate of spikes per tillering surveyed at each clipping date was 62.0-73.1 percent in barley, wheat, triticale and oat, and 56.0 percent in rye compared to that of optimum season sowing. The dry matter yield in spring sowing compared to 18 October was obtained about 71.7 percent in barley, 60.6 percent in wheat, 46.2 percent in rye, 70.2 percent in triticale and 110.9 percent in oat. It were increased in acid detergent fiber(ADF), neutral detergent fiber (NDF) and crude protein content, but decreased in digestible dry matter content(DDM) and relative feed value (RFV). The yield of DDM by spring sowing was decreased in barley, wheat, rye and triticale, but increased in oat. The yield of dry matter and DDM were higher in oat and triticale than that of barley, wheat and oat. So, regardless to clipping dates and cropping system, the appropriated crop for spring sowing was oat, and subsequently triticale and barley. It was not adopted for spring sowing in rye because of low rate of no. of spikes per tillers and yield. It was necessary eliminated winter growing nature by earlier sowing at the late of February after overwinter.
\end{abstract}

(Key words : Whole-crop silage, Winter cereal crop, Spring sowing, Feed quality)

충남농업기술원 (Chungnam Provincial ARES, Yesan, 340-861, Korea)

${ }^{1}$ 국립식량과학원 벼맥류부 (Dept. Rice and Winter Cereal Crop, NICS, RDA, Iksan, 570-080, Korea)

${ }^{2}$ 공주대학교 산업과학대학 (Dept. of Plant Resources, Kongju National University, Yesan, 340-702, Korea)

Corresponding author: Jung Il Ju, Chungnam Provincal ARES, Yesan-Gun, 340-861, Korea.

Tel: +82-41-330-6250, Fax: +82-41-330-6259, E-mail: cnswhtbar@korea.kr 


\section{I. 서 론}

맥류는 가을 파종시기에 강우 또는 벼 수확 작업과의 농작업 중첩 등으로 파종을 완료하지 못하는 경우가 발생되고, 이 때 준비된 종자를 활용하여 봄 파종하고자 하는 경우 총체맥류에 따라 출수 여부, 조사료 생산량 및 재배기술에 대한 보고가 미흡한 편이다. 또한 사료작물을 단지화, 집단화 재배하기 위하여 단일 작물의 대면적 재배보다 초종과 품종을 고려하여 파종 하는 것이 파종 및 수확작업에 투입되는 농기 계의 집중현상을 해소할 수 있다. 특히 사료작 물은 건물수량이 최고이면서 사료가치가 높은 시기에 예취해야 하는데 단일작물을 대면적으 로 재배하게 되면 작업일정상 일부를 조기 혹 은 늦게 수확하게 되어 품질의 저하를 초래할 수 있다. 따라서 적기 수확 및 농기계 작업의 집중현상 해소를 위하여 여러 가지 사료작물의 재배면적 안배 및 파종시기 조절 등의 방법을 고려할 수 있는데, 총체맥류의 봄 파종도 한 가지 방법이 될 수 있을 것이다.

동계작물인 맥류의 봄 파종 가능여부는 파성 으로 제시되는데, 일반적으로 보리는 봄 파종 시 파성 I $\sim \mathrm{III}$ 정도인 품종이 안전하고, 파성 $\mathrm{IV}$ 이상인 품종은 추파성을 소거한 후 파종하여 야 하는 것으로 알려져 있다(조 등, 1987; 하, 2000b; 2000c). 그런데 보리와 밀은 품종별로 파성이 제시되어 있으나, 트리티케일, 호밀 등 은 제시되지 않지 않아 이들 작물에 대하여 봄 파종이 가능한지 여부에 대한 판단 자료가 미 흡하다.

이에 총체맥류의 재배면적이 증가함에 따라 봄에 파종하고자 할 경우 총체맥류 주요 품종 에 대하여 초종별로 봄 파종시 생육, 조사료 생산성 및 사료가치에 대해서 보고하는 바이다.

\section{ㅍ. 재료 및 방법}

본 시험은 청보리, 밀, 호밀, 트리티케일, 귀
리 등 총체맥류 주요 품종에 대하여 봄 파종시 출수 여부, 생육, 수량 및 사료가치 등을 가을 적기파종과 비교하고자 충남농업기술원 (예산) 밭 사료포에서 2008/2009년에 수행되었다.

시험작물과 품종은 청보리 (영양 보리, 파성 I ), 밀 (금강 밀, 파성 II), 호밀 (곡우 호밀, 파 성 III 추정), 트리티케일 (신영 트리티케일, 파 성 III 추정), 귀리(삼한 귀리, 파성 $\Pi$ 추정)로 하였다. 파종기는 봄 파종으로 2월 23일과 3 월 10 일 2 시기를 두었고, 이를 10 월 18 일 적기 파 종과 비교하였다. 파종량은 청보리 18 , 밀 18 , 호밀 20 , 귀리 15 , 트리티케일 $8 \mathrm{~kg} / 10 \mathrm{a}$ 로 하였 고, 파종방법은 줄뿌림 파종하였는데 휴폭 25 $\mathrm{cm}$, 파폭 $5 \mathrm{~cm}$ 으로 하여 6 열을 파종하였고, 휴 장은 $600 \mathrm{~cm}$ 이었다. 시비량은 토양분석 후 종 실용 보리의 진단시비량에 따랐고, 이중 질소 는 $30 \%$ 증량하였다. 시비방법은 인산과 칼리는 전량 기비로 시용하였고, 질소는 기비와 추비 를 50:50으로 나누어 분시하였는데, 기비는 파 종전 살포하고 로타리작업 하였으며, 추비는 3 월 2 일에 시용하였다. 시험구 배치는 각 파종 시기별로 난괴법 3 반복으로 하였다.

생초 및 건물수량을 조사하기 위한 예취시기 는 청보리와 밀은 황숙기, 호밀은 출수 후 10 일, 트리티케일과 귀리는 유숙기로서 출수 후 20 일에 예취하였다. 예취시기에 지상부 생육으 로 초장, 이삭수 등을 조사하였고, 조사료 수량 은 6열중 가운데 4 열 $4 \mathrm{~m}$ 예취하여 조사하였 다.

사료가치 분석시료는 생초수량을 조사하기 위하여 예취한 시료에서 생체 $500 \mathrm{~g}$ 을 취하여 열풍건조기로 $70^{\circ} \mathrm{C}$ 에서 60 시간 건조하였다. 단 백질 함량은 $\mathrm{AOAC}$ (1995)으로 분석하였는데 사용기기는 Digestion unit/250ml (Foss, DS2500); KT 2400 2460 (FOSS) 이었다. Acid detergent fiber (ADF)와 Neutral detergent fiber (NDF)는 Goering과 Van Soest (1970)의 방법으로 분석하 였는데 사용기기는 Fiber analyzer(ANKOM $2000)$ 이었다. 가소화건물함량 (DDM, digestible 
dry matter $)$ 은 $\mathrm{DDM}=88.9-(0.779 \times \mathrm{ADF})$ 의 계산 식으로 산출하였고, 상대사료가치 $(\mathrm{RFV}$, Relative feed value $)$ 는 $\mathrm{RFV}=\mathrm{DDM}(\%) \times(120 / \mathrm{NDF}) / 1.29$ 계산식 (Holland 등, 1990)으로 산출하였다.

\section{III. 결과 및 고찰}

\section{1. 출현기, 출수기 및 성숙기}

총체맥류 5 초종에 대하여 봄 파종시 출현기, 출수기 및 성숙기를 10 월 18 일 적기파종과 비 교하여 나타낸 것은 Table 1과 같다.

출현일수는 가을 적기 파종시 작물에 따라 8 $\sim 12$ 일이 소요되었고, 봄 파종시 2월 23일 파종 은 21 25일, 3월 10일 파종은 12 14일이 소요 되었으며, 지온이 상대적으로 낮았던 봄 파종 에서 출현일수가 길었다. 작물별로는 2 월 23 일 봄 파종시 호밀과 트리티케일이 다른 작물에 비하여 출현이 빨랐고, 삼한 귀리가 다른 작물 에 비하여 1 4일 출현이 늦었다. 봄 파종시 출 수기는 가을파종에 비교하여 영양 보리 16일, 금강 밀 20일, 곡우 호밀 19일, 신영 트리티케 일 18일, 삼한 귀리 9일 지연되었다. 2월 23일
과 3 월 10 일 봄 파종을 비교하여 보면 영양 보 리 3일, 금강 밀 9일, 곡우 호밀, 신영 트리티 케일과 삼한 귀리 4일 차이가 있었는데 봄 파 종시기가 빠를수록 출수기도 빠른 경향이었다. 봄 파종시 성숙기는 가을파종에 비교하여 영양 보리 13일, 금강 밀 14일, 곡우 호밀 17일, 신 영 트리티케일 15 일, 삼한 귀리 6일 지연되었 다. 성숙기는 출수기와 달리 봄 파종시기에 따 라 비슷하거나 3 일 정도 차이가 있었고, 출수 기 이후 성숙기까지의 성숙일수는 봄파종시 가 을파종에 비교하여 영양 보리 3일, 금강 밀 6 일, 곡우 호밀 2일, 신영 트리티케일 3일, 삼한 귀리 3 일 짧았다.

\section{2. 생육단계별 적산온도 비교}

총체맥류 5 초종에 대하여 파종시기별 파종 기 출현기, 출현기 출수기, 출수기 성숙기등 생 육단계별로 $0^{\circ} \mathrm{C}$ 이상의 평균온도를 합계한 적 산온도를 나타낸 것은 Table 2와 같다.

파종부터 출현기까지의 지온 (지중 $5 \mathrm{~cm}$ )에 대하여 2월 23 일과 3 월 10 일 봄 파종을 평균하 면 영양 보리 $109^{\circ} \mathrm{C}$, 금강 밀 $117^{\circ} \mathrm{C}$, 곡우 호

Table 1. Comparisons of emergence, heading and maturing date between the spring sowing and the optimum season sowing in winter cereal crops for whole-crop forage use

\begin{tabular}{|c|c|c|c|c|c|c|c|c|c|}
\hline \multirow{2}{*}{$\begin{array}{c}\text { Crop } \\
\text { (Variety) }\end{array}$} & \multicolumn{3}{|c|}{$\begin{array}{l}\text { Days from sowing to } \\
\text { emergence }\end{array}$} & \multicolumn{3}{|c|}{ Heading date } & \multicolumn{3}{|c|}{ Maturing date } \\
\hline & 18 Oct. & 23 Feb. & 10 Mar. & 18 Oct. & $23 \mathrm{Feb}$ & 10 Mar. & 18 Oct. & 23 Feb. & 10 Mar. \\
\hline $\begin{array}{c}\text { Barley } \\
\text { (Youngyang) }\end{array}$ & 8 & 23 & 13 & 29 Apr. & 13 May & 16 May & 3 June & 15 June & 16 June \\
\hline $\begin{array}{c}\text { Wheat } \\
\text { (Keumkang) }\end{array}$ & 8 & 24 & 13 & 3 May & 18 May & 27 May & 11 June & 20 June & 29 June \\
\hline $\begin{array}{l}\text { Rye } \\
\text { (Gogu) }\end{array}$ & 8 & 21 & 12 & 24 Apr. & 11 May & 15 May & 15 June & 1 July & 3 July \\
\hline $\begin{array}{c}\text { Triticale } \\
\text { (Shinyoung) }\end{array}$ & 8 & 21 & 13 & 6 May & 22 May & 26 May & 17 June & 1 July & 3 July \\
\hline $\begin{array}{c}\text { Oat } \\
\text { (Samhan) }\end{array}$ & 12 & 25 & 14 & 19 May & 26 May & 30 May & 19 June & 24 June & 26 June \\
\hline
\end{tabular}


Table 2. Comparisons of accumulative temperature between the spring sowing and the optimum season sowing in winter cereal crops for whole-crop forage use

\begin{tabular}{|c|c|c|c|c|c|c|c|c|c|}
\hline \multirow{2}{*}{$\begin{array}{c}\text { Crop } \\
\text { (Variety) }\end{array}$} & \multicolumn{3}{|c|}{$\begin{array}{l}\text { From sowing } \\
\text { to emergence }\end{array}$} & \multicolumn{3}{|c|}{$\begin{array}{l}\text { From emergence } \\
\text { to heading }\end{array}$} & \multicolumn{3}{|c|}{$\begin{array}{l}\text { From heading } \\
\text { to maturing }\end{array}$} \\
\hline & 18 Oct. & 23 Feb. & 10 Mar. & 18 Oct. & 23 Feb. & 10 Mar. & 18 Oct. & 23 Feb. & 10 Mar. \\
\hline $\begin{array}{c}\text { Barley } \\
\text { (Youngyang) }\end{array}$ & 121 & 102 & 116 & 888 & 651 & 629 & 615 & 611 & 586 \\
\hline $\begin{array}{c}\text { Wheat } \\
\text { (Keumkang) }\end{array}$ & 121 & 119 & 116 & 948 & 708 & 824 & 710 & 649 & 695 \\
\hline $\begin{array}{l}\text { Rye } \\
\text { (Gogu) }\end{array}$ & 121 & 72 & 112 & 835 & 639 & 626 & 902 & 1,016 & 992 \\
\hline $\begin{array}{c}\text { Triticale } \\
\text { (Shinyoung) }\end{array}$ & 121 & 72 & 116 & 997 & 818 & 803 & 783 & 836 & 806 \\
\hline $\begin{array}{c}\text { Oat } \\
\text { (Samhan) }\end{array}$ & 165 & 131 & 119 & 1,174 & 837 & 881 & 608 & 595 & 561 \\
\hline
\end{tabular}

₹ Soil temperature was measured at $5 \mathrm{~cm}$ underground.

밀 $92^{\circ} \mathrm{C}$, 신영 트리티케일 $94^{\circ} \mathrm{C}$, 삼한 귀리 $125^{\circ} \mathrm{C}$ 로서 내한성이 약한 삼한 귀리가 출현까 지의 지온 적산온도가 많았고, 내한성이 강한 곡우 호밀과 신영 트리티케일이 적었다. 가을 파종과 봄 파종을 비교하여 보면 내한성이 강 한 호밀과 트리티케일에서 $27 \sim 29^{\circ} \mathrm{C}$ 의 차이가 있을 뿐 보리, 밀, 귀리는 거의 비슷하였다. 출 현기부터 출수기까지의 평균기온에 대한 적산 온도는 작물과 파종시기에 따른 차이가 뚜렷하 였다. 2월 23 일과 3 월 10 일 봄 파종을 평균하 면 영양 보리 $640^{\circ} \mathrm{C}$, 금강 밀 $766^{\circ} \mathrm{C}$, 곡우 호 밀 $632^{\circ} \mathrm{C}$, 신영 트리티케일 $810^{\circ} \mathrm{C}$, 삼한 귀리 $859^{\circ} \mathrm{C}$ 로서 출수기가 늦은 삼한 귀리, 신영 트 리티케일이 많았고, 출수기가 빠른 곡우 호밀 과 영양 보리가 적었다. 봄 파종시 평균기온에 대한 적산온도를 가을파종과 비교하여 보면 영 양 보리 $248^{\circ} \mathrm{C}$, 금강 밀 $182^{\circ} \mathrm{C}$, 곡우 호밀 203 ${ }^{\circ} \mathrm{C}$, 신영 트리티케일 $187^{\circ} \mathrm{C}$, 삼한 귀리 $315^{\circ} \mathrm{C}$ 차이가 있었는데 이는 월동기간에 기인하였다. 출수기부터 성숙기까지의 평균기온에 대한 적 산온도는 출현기부터 출수기까지의 적산온도에 비하여 작물과 파종시기간 차이가 적었다. 2 월 23 일과 3 월 10 일 봄 파종을 평균하면 영양 보
리 $598^{\circ} \mathrm{C}$, 금강 밀 $672^{\circ} \mathrm{C}$, 곡우 호밀 $1,004^{\circ} \mathrm{C}$, 신영 트리티케일 $821^{\circ} \mathrm{C}$, 삼한 귀리 $578^{\circ} \mathrm{C}$ 로서 등숙기간이 길었던 곡우 호밀이 많았고 다음은 신영 트리티케일이었으며, 상대적으로 출수가 늦고 고온기에 등숙되는 삼한 귀리가 적었다. 가을 파종과 봄 파종을 비교하여 보면 곡우호 밀을 제외하고는 비슷한 수준이었다. 이 등 (2000)은 보리 품종중 파성 I 과 IV인 2 품종 을 시험재료로 하여 수원지방에서 봄 파종시 생육단계별 적산온도는 파종부터 출현까지 111 $\sim 142^{\circ} \mathrm{C}$, 출현부터 출수까지 $683 \sim 756^{\circ} \mathrm{C}$, 파종부 터 성숙기까지 $1,274 \sim 1,326^{\circ} \mathrm{C}$ 이었고, 파성이 낮은 품종이 상대적으로 봄 파종에 적합하였으 며, 김 등 (1998)은 수원지방에서 적어도 3월 10 일 이전에 파종하여야 한다고 하였는데 이들 의 보고와 같은 경향이었다.

\section{3. 생육특성}

초장은 봄 파종시기간 차이는 없었고, 가을 파종과 비교하여 봄 파종에서 영양 보리, 금강 밀, 곡우 호밀, 신영 트리티케일은 약 11 17 cm 작았으나 삼한 귀리는 차이가 없었다. 채 등 
(1973)은 춘파성이 높은 품종은 봄 파종시기에 따른 간장의 변화는 거의 없었으나 춘파성이 낮은 품종들은 파종이 늦어짐에 따라 간장이 크게 단축되었다고 하였는데, 본 시험도 귀리 품종을 제외하면 대체로 비슷한 경향이었다. 이삭수는 봄 파종시 삼한 귀리가 다른 총체맥 류에 비하여 많았고, 곡우 호밀이 가장 적었으 며, 가을파종에 비하여 영양 보리 $32.0 \%$, 금강 밀 $37.9 \%$, 신영 트리티케일 $28.0 \%$, 삼한 귀리 $18.5 \%$ 감소되었다. 곡우 호밀은 2월 23 일 파종 과 3 월 10 일 파종에서 이삭수의 차이가 많았는 데, 이는 3 월 10 일 파종에서 파성 소거가 이루 어지지 않는 것으로 판단되었고, 다른 총체맥 류에 비하여 봄 재배에 부적합한 것으로 사료 되었다. 일반적으로 귀리는 옥수수 수확 후 뒷 그루 작물로 많이 재배하는 작물로서 파성을 소거하지 않아도 출수되는데, 봄 파종시 2월 말 파종보다 3월 상순 파종에서 생육이 양호하 였다. 총체맥류는 작물에 따라 지상부 전체 건 물중에서 이삭의 구성비율이 다른데 보통 청보 리와 밀이 높고, 호밀이 낮으며, 귀리는 이삭비
율은 높지만 이삭이 길고 지경이 많아 실제 알 곡의 비율은 낮은 작물이다. 봄 파종시기를 평 균하여 가을파종과 비교하면 지상부에서 이삭 이 차지하는 비율은 영양 보리와 삼한 귀리는 비슷하였고, 금강 밀, 곡우 호밀, 신영 트리티 케일은 증가하였는데, 이는 밀, 호밀, 트리티케 일 등에서 봄 파종시 가을파종에 비하여 간장 이 짧은데 기인하였다.

각각 총체맥류의 수확시기에 일정면적의 총 경수에서 출수된 이삭수의 비율을 나타낸 것은 Fig. 1과 같다. 총체맥류는 보통 가을에 파종하 여 겨울동안 저온에 의하여 파성이 소거되어야 출수되는 것으로 알려져 있다. 따라서 봄 파종 시 총 경수에서 출수된 이삭수의 비율이 높다 는 것은 봄 파종시 낮은 지온으로 최아종자 상 태에서 파성이 소거되어 정상적인 출수가 이루 어지고, 일정량의 조사료 수확이 가능함을 의 미한다. 봄 파종시 총 경수에서 출수된 이삭의 비율은 영양 보리 $67.4 \%$, 금강 밀 $62.0 \%$, 곡우 호밀 $56.0 \%$, 신영 트리티케일 $73.1 \%$, 삼한 귀 리 $67.4 \%$ 로서 신영 트리티케일에서 그 비율이

Table 3. Comparisons of growth characteristics between the spring sowing and the optimum season sowing in winter cereal crops for whole-crop forage use

\begin{tabular}{|c|c|c|c|c|c|c|c|c|c|}
\hline \multirow{2}{*}{$\begin{array}{c}\text { Crop } \\
\text { (Variety) }\end{array}$} & \multicolumn{3}{|c|}{ Plant height $(\mathrm{cm})$} & \multicolumn{3}{|c|}{ No. of spike per $\mathrm{m}^{2}$} & \multicolumn{3}{|c|}{$\begin{array}{l}\text { Ratio of spike wt. } \\
\text { per aerial parts }\end{array}$} \\
\hline & 18 Oct. & $23 \mathrm{Feb}$ & 10 Mar. & 18 Oct. & 23 Feb. & 10 Mar. & 18 Oct. & 23 Feb. & 10 Mar. \\
\hline $\begin{array}{c}\text { Barley } \\
\text { (Youngyang) }\end{array}$ & $93 c$ & $74 d$ & $78 d$ & $556 c$ & $369 b$ & $387 b$ & $58.2 a$ & $59.0 \mathrm{a}$ & $55.7 a$ \\
\hline $\begin{array}{c}\text { Wheat } \\
\text { (Keumkang) }\end{array}$ & $92 c$ & $78 d$ & $79 d$ & $746 b$ & $474 b$ & $452 b$ & $47.3 b$ & $53.9 \mathrm{ab}$ & $55.3 a$ \\
\hline $\begin{array}{l}\text { Rye } \\
\text { (Gogu) }\end{array}$ & $140 a$ & $124 a$ & $133 a$ & $983 a$ & $397 b$ & $191 c$ & $9.5 d$ & $13.2 d$ & $12.4 c$ \\
\hline $\begin{array}{c}\text { Triticale } \\
\text { (Shinyoung) }\end{array}$ & $125 b$ & $111 b$ & $114 b$ & $549 c$ & $389 b$ & $401 b$ & $32.9 c$ & $41.1 c$ & $47.2 b$ \\
\hline $\begin{array}{c}\text { Oat } \\
\text { (Samhan) }\end{array}$ & $96 c$ & $98 c$ & $100 c$ & $838 a b$ & $733 a$ & $633 a$ & $52.5 b$ & $48.3 b$ & $54.4 a$ \\
\hline F-value & $* *$ & $* *$ & $* *$ & $* *$ & $* *$ & $* *$ & $* *$ & $* *$ & $* *$ \\
\hline C.V. & 2.9 & 3.1 & 4.5 & 6.1 & 12.9 & 10.0 & 4.57 & 4.80 & 4.87 \\
\hline
\end{tabular}

₹ Same letters in each column are not significantly different at the 5\% level of DMRT. 


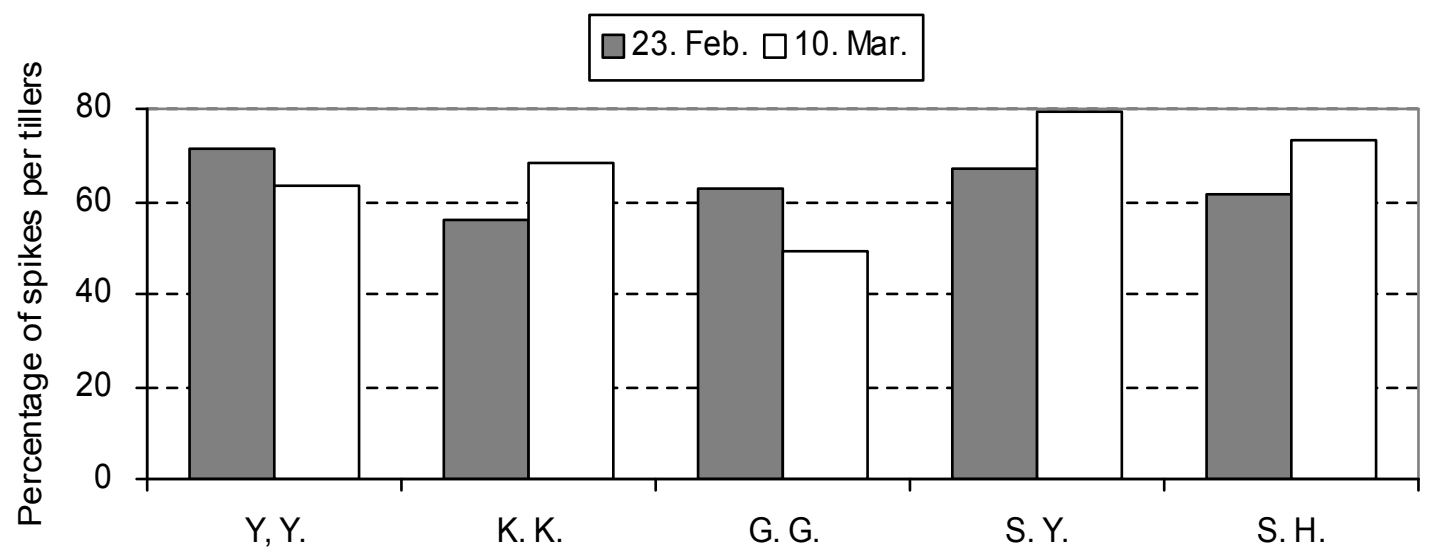

Fig. 1. Rates of spikes per tillers at optimum cutting date of each crops (Y.Y.- Youngyang (Barley), K.K.-Keumkang(Wheat), G.G-Gogu (Rye), S.Y.-Shinyoung (Triticale), S.H.Samhan (Oat)).

높았고, 곡우 호밀이 가장 낮았다. 또한 곡우 호밀은 2월 23 일 파종 $62.6 \%, 3$ 월 10 일 파종 $49.3 \%$ 로서 봄 파종시기가 늦어지면 출수된 이 삭의 비율이 낮았는데, 봄 파종시기에 따라 출 수가 불안정하다는 것을 의미하였다. 보리는 주간 및 분얼에 있어서 상사생육의 법칙이 적 용되고 있고, 분얼의 발생은 품종, 재배환경 등 의 영향을 받는데 일반적으로 추파성의 만생종 에서 분얼수가 많고 춘파성의 조생종에서는 분 얼수가 적은 경향이다 (하, 2000a). 신 및 Hirosi (1995)는 보리의 가을 파종에서 유효경 발생율 과 주당 유효경수는 파종시기가 빠를수록 높았 고, 유효 이삭수는 조파보다 적파에서 많았다 고 하였는데, 본 시험은 가을 파종에 적합한 품종을 봄에 파종한 경우로서 만파에 해당하므 로 이러한 결과와 대체로 같은 경향으로 판단 할 수 있었다. 또한 채 등 (1973)은 보리에서 봄 파종시기가 늦어질수록 주간엽수와 분얼수 가 증가되어 과도한 영양생장을 지속하고 출수 가 늦어지는데 보리의 봄 파종기는 2 월 하순 3월 상순이라고 하였다.

\section{4. 생초 및 건물수량}

총체맥류 5 초종에서 수량을 조사하기 위한
예취시기는 Table 4 와 같다. 영양 보리는 황숙 기에 예취하였는데 10 월 18 일 파종은 5 월 24 일 이었고, 2 월 23 일과 3 월 10 일 봄 파종은 가을 적기파종에 비하여 14 15일 늦어졌다. 금강 밀 은 황숙기에 예취하였는데 10 월 18 일 파종은 6 월 7일이었고, 봄 파종은 가을 적기파종에 비 하여 8 11일 늦어졌다. 곡우 호밀은 출수 후 10 일에 예취하였는데 10 월 18 일 파종은 5 월 7 일이었고, 봄 파종은 가을 적기파종에 비하여 17 20일 늦어졌다. 신영 트리티케일은 출수 후 20 일에 예취하였는데 10 월 18 일 파종은 6 월 1 일 이었고, 봄 파종은 가을 적기파종에 비하여 13 17일 늦어졌다. 삼한 귀리는 출수 후 20일 에 예취하였는데 10 월 18 일 파종은 6 월 7 일이 었고, 봄 파종은 가을 적기파종에 비하여 8 11 일 늦어졌다. 봄 파종시 수확시기는 곡우 호밀 이 가장 빨랐고, 다음은 영양 보리이었으며, 금 강 밀, 신영 트리티케일 및 삼한 귀리는 6월 중순으로서 비슷한 시기에 수확되었다.

가을 파종과 봄 파종시 청보리, 밀, 호밀, 트 리티케일, 귀리 등 5 초종의 총체맥류에 대하여 각 총체맥류의 적정 수확시기에 조사한 수량은 Table 5와 같다.

생초수량은 2월 23 일 봄 파종이 3월 10 일 봄 파종에 비하여 영양 보리 $6.7 \%$, 금강 밀 
Table 4. Clipping dates at the optimal harvesting stage of each crop for round-baled silage in winter cereal crops for whole-crop forage use

\begin{tabular}{|c|c|c|c|c|}
\hline \multirow{2}{*}{$\begin{array}{c}\text { Crop } \\
\text { (Variety) }\end{array}$} & \multirow{2}{*}{ Harvesting stage } & \multicolumn{3}{|c|}{ Clipping date } \\
\hline & & 18 Oct. & 23 Feb. & 10 Mar. \\
\hline $\begin{array}{c}\text { Barley } \\
\text { (Youngyang) }\end{array}$ & Yellow ripe stage & 24 May & 7 June & 8 June \\
\hline $\begin{array}{c}\text { Wheat } \\
\text { (Keumkang) }\end{array}$ & Yellow ripe stage & 7 June & 15 June & 18 June \\
\hline $\begin{array}{l}\text { Rye } \\
\text { (Gogu) }\end{array}$ & 10 Days after heading & 7 May & 24 May & 27 May \\
\hline $\begin{array}{c}\text { Triticale } \\
\text { (Shinyoung) }\end{array}$ & 20 Days after heading & 1 June & 14 June & 18 June \\
\hline $\begin{array}{c}\text { Oat } \\
\text { (Samhan) }\end{array}$ & 20 days after heading & 7 June & 15 June & 18 June \\
\hline
\end{tabular}

Table 5. Comparisons of fresh and dry matter yield between the spring sowing and the optimum season sowing in winter cereal crops for whole-crop forage use

\begin{tabular}{|c|c|c|c|c|c|c|c|c|c|}
\hline \multirow{2}{*}{$\begin{array}{c}\text { Crop } \\
\text { (Variety) }\end{array}$} & \multicolumn{3}{|c|}{ Fresh yield(ton/ha) } & \multicolumn{3}{|c|}{ Dry matter rate(\%) } & \multicolumn{3}{|c|}{ Dry matter yield(ton/ha) } \\
\hline & 18 Oct. & 23 Feb. & 10 Mar. & 18 Oct. & 23 Feb. & 10 Mar. & 18 Oct. & 23 Feb. & 10 Mar. \\
\hline $\begin{array}{c}\text { Barley } \\
\text { (Youngyang) }\end{array}$ & $30.42 b$ & $26.08 a b$ & $24.43 a$ & $40.2 a$ & $36.5 a$ & $33.8 b$ & $12.18 a b$ & $9.46 b$ & $8.01 b$ \\
\hline $\begin{array}{c}\text { Wheat } \\
\text { (Keumkang) }\end{array}$ & $33.03 b$ & $22.85 b$ & $17.62 b$ & $42.4 a$ & $42.0 a$ & $42.2 a$ & $14.01 a$ & $9.61 b$ & $7.37 b c$ \\
\hline $\begin{array}{l}\text { Rye } \\
\text { (Gogu) }\end{array}$ & $48.29 a$ & $23.88 b$ & $23.78 a$ & $24.4 c$ & $23.7 b$ & $21.8 c$ & $11.67 a b$ & $5.65 c$ & $5.14 c$ \\
\hline $\begin{array}{c}\text { Triticale } \\
\text { (Shinyoung) }\end{array}$ & $39.43 a b$ & $29.82 a$ & $23.47 a$ & $37.2 a b$ & $36.5 a$ & $41.5 a$ & $14.64 a$ & $10.86 a b$ & $9.69 a b$ \\
\hline $\begin{array}{c}\text { Oat } \\
\text { (Samhan) }\end{array}$ & $31.33 b$ & $31.65 a$ & $23.97 a$ & $32.8 b$ & $37.5 a$ & $44.6 a$ & $10.11 b$ & $11.76 a$ & $10.68 a$ \\
\hline F-value & $* *$ & $*$ & $*$ & $* *$ & $* *$ & $* *$ & $* *$ & $* *$ & $* *$ \\
\hline C.V. & 9.63 & 12.09 & 11.00 & 4.71 & 5.84 & 5.48 & 9.04 & 7.00 & 10.60 \\
\hline
\end{tabular}

₹ Same letters in each column are not significantly different at the $5 \%$ level of DMRT.

$29.6 \%$, 곡우 호밀 $0.4 \%$, 신영 트리티케일 로 고온에서 생장하는 관계로 줄기의 굵기가 $27.0 \%$, 삼한 귀리 $32.0 \%$ 증수되었다. 따라서 가늘게 생장하였기 때문인 것으로 관찰되었다. 봄 파종시기가 빠를수록 생초수량이 증수되었 봄 파종시 평균 생초수량을 가을 파종과 비교 는데 그 정도는 귀리, 밀, 트리티케일이 많았 하여 보면 영양 보리 $83.0 \%$, 금강 밀 $61.3 \%$, 고, 다음은 보리이었으며, 호밀은 적었다. 일부 곡우 호밀 $49.3 \%$, 신영 트리티케일 $67.6 \%$, 삼 총체맥류에서 봄 파종시 초장이 비슷하고 이삭 한 귀리 $88.8 \%$ 수준이었다. 봄 파종과 가을 파 수의 차이가 적었음에도 불구하고 생초수량에 종을 비교하여 생초수량의 변화가 작은 작물은 차이가 있는 것은 파종시기가 늦으면 상대적으 귀리, 청보리 등 이었고, 호밀이 가장 높았다. 
따라서 봄 파종시 생초수량은 작물에 따라 평 균 20.2톤 27.8톤/ha로서 차이가 크지 않았지만, 가을 파종과 비교하여 재배 안정성은 귀리와 청보리가 높고, 다음은 트리티케일이었으며, 호 밀이 가장 낮았다.

건물수량은 2 월 23 일 봄 파종이 3 월 10 일 봄 파종에 비하여 영양 보리 $18.1 \%$, 금강 밀 $30.4 \%$, 곡우 호밀 $9.9 \%$, 신영 트리티케일 12.1 $\%$, 삼한 귀리 $10.1 \%$ 증수되었다. 따라서 봄 파 종시기가 빠를수록 생체수량 뿐만 아니라 건물 수량도 증수되었으며, 이러한 결과는 채 등 (1973)이 보리에서 봄 파종시기가 늦어질수록 감수되었다는 보고와 같은 경향이었다. 봄 파 종을 가을 파종과 비교하여 보면 영양 보리 $71.7 \%$, 금강 밀 $60.6 \%$, 곡우 호밀 $46.2 \%$, 신영 트리티케일 $70.2 \%$, 삼한 귀리 $110.9 \%$ 수준이었 다. 따라서 총체맥류를 봄에 파종하면 가을에 파종한 것에 비하여 귀리는 건물수량의 변화가 적었고, 다음은 청보리와 트리티케일 이었으며, 호밀이 가장 높았다. 한편 연 등 (1991)과 송 등 (2009)은 맥류 종류에 따라 조사료 생산성 및 사료가치가 다르고, 이 등 (2000)은 봄 파종
시기가 늦으면 늦을수록 천립중이 감소하고 미 등숙립이 증가하여 종실수량이 감소되었다고 하였는데, 본 시험에서는 지상부 전체의 조사 료 생산을 목적으로 함으로 봄 파종시기에 따 른 건물수량의 증감에 미치는 영향 요인을 정 확히 분석할 수 없었다.

\section{5. 사료가치}

총체맥류 5 초종에 대하여 봄 파종시 $\mathrm{ADF}$, $\mathrm{NDF}$ 및 조단백질 함량을 10 월 18 일 파종과 비 교하여 나타낸 것은 Table 6과 같다.

$\mathrm{ADF}$ 함량을 비교하여 보면 영양 보리, 금강 밀, 신영 트리티케일 등은 2월 23일 봄 파종이 3월 10 일 봄 파종에 비하여 $1.6 \sim 2.1 \%$ 낮았고, 곡우 호밀과 삼한 귀리는 각각 $0.5,1.6 \%$ 높았 다. 또한 봄 파종은 가을파종에 비하여 영양 보리 $2.7 \%$, 금강 밀 $1.2 \%$, 곡우 호밀 $6.5 \%$, 신 영 트리티케일 $1.0 \%$, 삼한 귀리 $6.7 \%$ 높았다. $\mathrm{NDF}$ 함량을 비교하여 보면 영양 보리, 금강 밀, 신영 트리티케일 등은 2월 23일 봄 파종이 3 월 10 일 봄 파종에 비하여 낮았고, 곡우 호밀

Table 6. Comparisons of acid detergent fiber (ADF), neutral detergent fiber (NDF) and crude protein $(\mathrm{CP})$ between the spring sowing and the optimum season sowing in winter cereal crops for whole-crop forage use

\begin{tabular}{|c|c|c|c|c|c|c|c|c|c|}
\hline \multirow{2}{*}{$\begin{array}{c}\text { Crop } \\
\text { (Variety) }\end{array}$} & \multicolumn{3}{|c|}{$\mathrm{ADF}(\%)$} & \multicolumn{3}{|c|}{$\mathrm{NDF}(\%)$} & \multicolumn{3}{|c|}{$\mathrm{CP}(\%)$} \\
\hline & 18 Oct. & $23 \mathrm{Feb}$ & 10 Mar. & 18 Oct. & $23 \mathrm{Feb}$ & 10 Mar. & 18 Oct. & 23 Feb. & 10 Mar. \\
\hline $\begin{array}{c}\text { Barley } \\
\text { (Youngyang) }\end{array}$ & $20.3 b$ & $22.2 c$ & $23.9 c$ & $42.5 b$ & $43.4 d$ & $46.0 c$ & $8.0 a$ & $9.2 a b$ & $9.4 a$ \\
\hline $\begin{array}{l}\text { Wheat } \\
\text { (Keumkang) }\end{array}$ & $22.0 b$ & $22.2 c$ & $24.3 c$ & $44.0 \mathrm{~b}$ & $43.5 d$ & $47.1 c$ & $8.0 a$ & $10.8 a b$ & $10.6 a$ \\
\hline $\begin{array}{l}\text { Rye } \\
\text { (Gogu) }\end{array}$ & $32.0 a$ & $33.0 a$ & $32.5 a$ & $56.9 a$ & $61.5 a$ & $58.5 a$ & $9.6 a$ & $11.5 a$ & $11.6 a$ \\
\hline $\begin{array}{c}\text { Triticale } \\
\text { (Shinyoung) }\end{array}$ & $26.3 a b$ & $26.5 b$ & $28.1 b$ & $49.4 a b$ & $50.9 c$ & $52.2 b$ & $8.0 a$ & $9.3 a b$ & $9.3 a$ \\
\hline $\begin{array}{c}\text { Oat } \\
\text { (Samhan) }\end{array}$ & $24.9 b$ & $32.5 a$ & $30.7 a$ & $45.3 b$ & $56.9 b$ & $52.1 b$ & $8.8 a$ & $8.4 b$ & $9.0 a$ \\
\hline F-value & $* *$ & $* *$ & $* *$ & $* *$ & $* *$ & $* *$ & $\mathrm{~ns}$ & * & $\mathrm{ns}$ \\
\hline C.V. & 7.75 & 3.13 & 2.96 & 10.95 & 2.90 & 2.53 & 9.83 & 9.45 & 10.96 \\
\hline
\end{tabular}

\# Same letters in each column are not significantly different at the $5 \%$ level of DMRT. 
과 삼한 귀리는 높았다. 또한 봄 파종은 가을 파종에 비하여 영양 보리, 금강 밀, 곡우 호밀, 신영 트리티케일, 삼한 귀리 모두 높았다. 조단 백질 함량은 2 월 23 일 파종과 3 월 10 일 파종에 서 귀리를 제외하고 다른 총체 맥류에서 차이 가 없었다. 또한 봄 파종은 가을 파종에 비하 여 영양 보리 $1.3 \%$, 금강 밀 $2.0 \%$, 곡우 호밀 $1.9 \%$, 신영 트리티케일 $1.3 \%$ 높았고, 삼한 귀 리는 비슷하였다. 따라서 총체맥류를 봄에 파 종하면 가을 파종에 비하여 $\mathrm{ADF}$ 함량, $\mathrm{NDF}$ 함량 및 조단백질 함량이 증가하는 것으로 나 타났다. 또한 봄 파종시기가 상대적으로 빠르 면 영양 보리, 금강 밀, 신영 트리티케일은 $\mathrm{ADF}$ 함량과 $\mathrm{NDF}$ 함량이 낮아졌고, 곡우 호밀 과 삼한 귀리는 높았으며, 조단백질 함량은 귀 리를 제외하곤 차이가 없는 것으로 나타났다. 한편 권 및 김(1992)은 호밀의 조·만생종 품 종, 파종시기 및 수확시기에 따라 사료가치가 달라진다고 하였고, 주 등(2009)은 총체맥류 5 초종에 대하여 예취시기별 사료가치를 분석한 바 있다. 김 및 김(1992)은 총체맥류중 귀리의
봄 파종에서 파종시기가 늦어질수록 $\mathrm{ADF}$, $\mathrm{NDF}$ 이 낮아졌고 조단백질 함량은 증가하였다 고 하였는데, 본 시험에서도 삼한귀리를 분석 하여 보면 비슷한 경향이었다.

$\mathrm{ADF}$ 함량과 $\mathrm{NDF}$ 함량은 Goering과 Van Soest (1970)의 방법에 의하여 최신식 자동 Fiber analyzer (ANKOM 2000)를 사용하여 분석 하였는데, 권 등 (2008), 김 등 (2003), 김 등 (2008) 및 송 등 (2009)의 보고와 비교하면 본 시험에서 분석치가 다소 낮았다. $\mathrm{ADF}$ 함량과 $\mathrm{NDF}$ 함량은 품종 (김 등, 2003; 김 등, 2008), 생육단계 (권 등, 2008; 송 등, 2009) 등에 따라 차이가 있고, 본 시험에서 분석치가 다소 낮았 던 것은 분석기기의 차이에 기인할 것으로 추 측 되었으나 다른 논문에서 분석기기에 대한 제시가 없어 고찰하는데 아쉬움이 있었다.

총체맥류 5 초종에 대하여 $\mathrm{ADF}$ 와 $\mathrm{NDF}$ 함량 을 근거로 산출한 가소화건물함량(DDM)과 상 대사료가치 $(\mathrm{RFV})$ 는 Table 7과 같다.

가소화건물함량을 비교하여 보면 영양 보리, 금강 밀, 신영 트리티케일 등은 2월 23일 봄

Table 7. Comparisons of digestible dry matter (DDM) and relative feed value (RFV) between the spring sowing and the optimum season sowing in winter cereal crops for whole-crop forage use

\begin{tabular}{|c|c|c|c|c|c|c|}
\hline \multirow{2}{*}{$\begin{array}{c}\text { Crop } \\
\text { (Variety) }\end{array}$} & \multicolumn{3}{|c|}{ DDM (\%) } & \multicolumn{3}{|c|}{ RFV } \\
\hline & 18 Oct. & 23 Feb. & 10 Mar. & 18 Oct. & 23 Feb. & 10 Mar. \\
\hline $\begin{array}{c}\text { Barley } \\
\text { (Youngyang) }\end{array}$ & $73.1 a$ & $71.6 a$ & $70.3 a$ & $160.4 a$ & $153.8 a$ & $142.3 a$ \\
\hline $\begin{array}{l}\text { Wheat } \\
\text { (Keumkang) }\end{array}$ & $71.7 a$ & $71.6 a$ & $70.0 a$ & $152.0 a b$ & $153.3 a$ & $138.3 a$ \\
\hline $\begin{array}{l}\text { Rye } \\
\text { (Gogu) }\end{array}$ & $64.0 b$ & $63.2 c$ & $63.6 c$ & $105.6 c$ & $95.5 c$ & $101.3 c$ \\
\hline $\begin{array}{c}\text { Triticale } \\
\text { (Shinyoung) }\end{array}$ & $68.4 a b$ & $68.2 b$ & $67.0 b$ & $129.2 b c$ & $124.9 b$ & $119.4 b$ \\
\hline $\begin{array}{c}\text { Oat } \\
\text { (Samhan) }\end{array}$ & $69.5 a$ & $63.6 c$ & $65.0 b$ & $143.1 a b$ & $104.0 c$ & $116.0 b$ \\
\hline F-value & $* *$ & $* *$ & $* *$ & $* *$ & $* *$ & $* *$ \\
\hline C.V. & 2.45 & 1.00 & 0.96 & 7.75 & 4.34 & 3.77 \\
\hline
\end{tabular}

\$ Same letters in each column are not significantly different at the $5 \%$ level of DMRT. 
파종이 3월 10 일 봄 파종에 비하여 $1.2 \sim 1.6 \%$ 높았고, 곡우 호밀은 비슷하였으며, 삼한 귀리 는 $1.4 \%$ 낮았다. 또한 봄 파종은 가을 파종에 비하여 영양 보리 $2.2 \%$, 금강 밀 $0.9 \%$, 곡우 호밀 $0.6 \%$, 신영 트리티케일 $3.3 \%$, 삼한 귀리 $5.2 \%$ 낮았다. 상대사료가치를 비교하여 보면 영양 보리, 금강 밀, 신영 트리티케일 등은 2월 23 일 봄 파종이 3 월 10 일 봄 파종에 비하여 높 았고, 곡우 호밀과 삼한 귀리는 낮았다. 또한 봄 파종은 가을 파종에 비하여 영양 보리, 금 강 밀, 곡우 호밀, 신영 트리티케일, 삼한 귀리 모두 낮았다. 따라서 총체맥류를 봄에 파종하 면 가을에 파종한 것에 비하여 가소화건물함량 과 상대사료가치가 낮아지는 단점이 있었다. 김 및 김(1992)는 귀리에서 봄 파종시 파종시 기가 빠를수록 사료가치가 낮았고, 같은 파종 기에서는 조생품종보다 만생품종이 사료기치가 높았는데 본 시험에서 귀리를 분석하여 보면 이와 비슷한 경향이었다.

\section{6. 가소화건물 수량}

가을 파종과 봄 파종시 청보리, 밀, 호밀, 트 리티케일, 귀리 등 5 초종의 총체맥류에 대하여
건물수량과 가소화건물함량으로 산출한 가소화 건물수량은 Fig. 2와 같다.

가소화 건물수량은 2 월 23 일 봄 파종이 3 월 10 일 봄 파종에 비하여 영양 보리 $20.5 \%$, 금강 밀 $33.9 \%$, 곡우 호밀 $9.5 \%$, 신영 트리티케일 $14.2 \%$, 삼한 귀리 $7.8 \%$ 증수되었다. 따라서 봄 파종시기가 빠를수록 건물수량 뿐만 아니라 가 소화건물 수량도 증수되는 경향이었다. 봄 파 종시 가소화건물 수량은 가을 파종에 비하여 영양 보리 $69.5 \%$, 금강 밀 $59.9 \%$, 곡우 호밀 $45.8 \%$, 신영 트리티케일 $69.3 \%$, 삼한 귀리 $102.3 \%$ 수준이었다. 따라서 총체맥류를 봄에 파종하면 가을에 파종한 것에 비하여 영양 보 리, 금강 밀, 곡우 호밀, 신영 트리티케일은 모 두 감수되었고, 삼한 귀리는 비슷하거나 증수 되었다. 봄 파종시 평균 가소화 건물수량은 삼 한 귀리 > 신영 트리티케일 > 영양 보리 > 금 강 밀 > 곡우 호밀 순으로 높았다. 따라서 예 취시기 등을 고려하지 않는다면 봄 파종은 귀 리가 가장 알맞은 것으로 나타났고, 다음은 신 영 트리티케일, 영양 보리 순이었으며, 곡우 호 밀은 부적합한 것으로 판단되었다. 총체맥류는 생육단계에 따라 사료가치가 다른데 (주 등, 2009), 신 및 김(1995)은 봄 파종의 귀리는 유

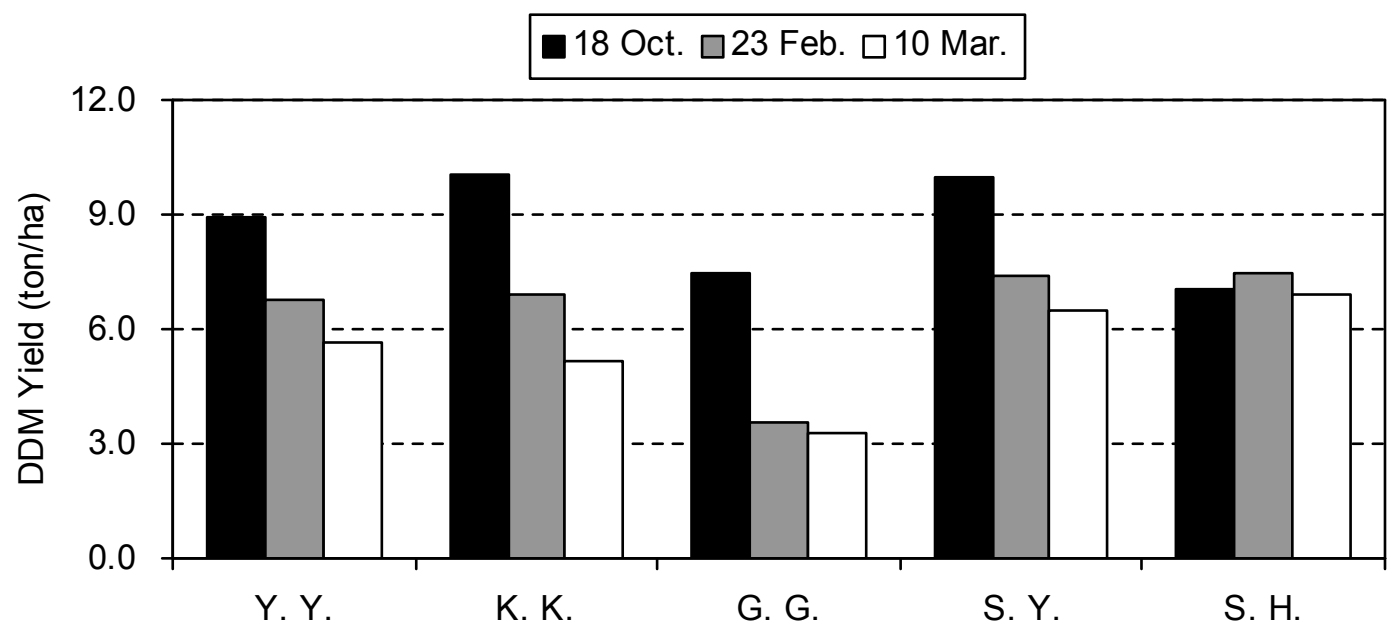

Fig. 2. Comparisons of DDM yield between the spring sowing and the optimum season sowing in winter cereal crops for whole-crop forage use (Y.Y.-Youngyang (Barley), K.K.Keumkang(Wheat), G.G-Gogu(Rye), S.Y.-Shinyoung (Triticale), S.H.-Samhan (Oat)). 
숙기가 사일리지 제조에 알맞다고 하였다.

\section{IV. 요 약}

본 시험은 청보리, 밀, 호밀, 트리티케일, 귀 리 등 총체맥류 주요 품종에 대하여 봄 파종시 출수 여부, 생육, 수량 및 사료가치 등을 적기 파종과 비교하고자 2008/2009년에 충남농업기 술원 (예산) 밭 사료포에서 수행되었다. 시험초 종 및 품종은 청보리 (영양, 파성 I ), 밀 (금강, 파성 II), 호밀 (곡우, 파성 III 추정), 트리티케 일(신영, 파성 III 추정), 귀리(삼한, 파성 II 추정)이었고, 파종기는 가을 적기파종 (10월 18 일)과 봄 파종 (2월 23일, 3월 10일)을 두었다. 출수기는 봄 파종시 가을 적기 파종에 비하여 청보리, 밀, 호밀, 트리티케일 등은 약 16 20 일, 귀리는 약 9일 늦었다. 봄 파종시 수확시기 는 영양 보리 (황숙기) 6월 8일, 곡우 호밀 (출 수 후 10 일) 5 월 25 일, 금강 밀 (황숙기), 신영 트리티케일 (유숙기) 및 삼한 귀리 (유숙기)는 6 월 17 일경 이었다. 봄 파종은 가을 파종에 비 하여 출현기부터 출수기까지의 적산온도의 감 소가 컸고, 파종기 출현기, 출수기부터 성숙기 까지의 적산온도는 큰 차이가 없었다. 전체 경 수에서 출수된 이삭수의 비율은 영양 보리, 금 강 밀, 신영 트리티케일, 삼한 귀리 등은 62.0 $\sim 73.1 \%$ 로서 정상적으로 출수되었고, 곡우호 밀은 $56.0 \%$ 로서 출수되지 않는 분얼이 많았다. 봄 파종시 건물수량은 삼한 귀리>신영 트리티 케일>영양 보리>금강 밀>곡우 호밀 순으로 많았고, 가을파종에 비하여 영양 보리 $71.7 \%$, 금강 밀 $60.6 \%$, 곡우 호밀 $46.2 \%$, 신영 트리티 케일 $70.2 \%$, 삼한 귀리 $110.9 \%$ 수준이었다. 총 체맥류를 봄에 파종하면 가을 파종에 비하여 $\mathrm{ADF}$ 함량, $\mathrm{NDF}$ 함량 및 조단백질 함량이 증 가하는 것으로 나타났고, 가소화건물함량과 상 대사료가치는 낮아졌다. 봄 파종시 평균 가소 화 건물수량은 삼한 귀리>신영 트리티케일> 영양 보리>금강 밀>곡우 호밀 순으로 높았
고, 가을에 파종한 것에 비하여 영양 보리, 금 강 밀, 곡우 호밀, 신영 트리티케일은 모두 감 수되었고, 삼한 귀리는 증수되었다. 따라서 예 취시기 등을 고려하지 않는다면 봄 파종은 귀 리가 가장 알맞은 것으로 나타났고, 다음은 신 영 트리티케일, 영양 보리 순이었으며, 곡우 호 밀은 부적합한 것으로 판단되었다. 또한 총체 맥류의 봄 파종 및 재배는 파성을 소거할 필요 가 있으므로 2 월 말 (경칩 전) 얼음이 풀리는 대로 가능하면 빨리 파종하여 낮은 지온으로 종자 상태에서 춘화처리가 되도록 할 필요가 있었다.

\section{$\mathrm{V}$. 인 용 문 헌}

1. 권영업, 백성범, 허화영, 박형호, 김정곤, 이재은, 이충근, 신진철. 2008. 총체사료용 맥류의 생육시 기 및 식물체 부위별 사료가치 변화. 한국작물학 회지. 53(2):144-149.

2. 권찬호, 김동암. 1992. 조-만생종 사초용 호밀의 파종 및 수확시기에 관한 연구. I. 파종시기별 수량 및 사료가치. 한초지. 12(4):246-252.

3. 김영진. 1998. 17세기 초 고상안의 대맥 춘화처 리에 관한 고찰. 한국맥류연구회지. 5:117-125.

4. 김원호, 서 성, 윤세형, 김기용, 조영무, 박태일, 고종민, 박근제. 2003. 사일리지용 우량 보리 품 종 선발. 2. 사료가치 및 TDN 수량. 한초지. 23(4):283-288.

5. 김종근, 정의수, 서 성, 김맹중, 이종경, 윤세형, 임영철, 조용민. 2008. 수확시기 및 품종이 총체 벼 사일리지의 품질에 미치는 영향. 초지조사료 지. 28(1):29-34.

6. 김종림, 김동암. 1992. 춘계 파종시기가 조-만생 연맥의 생장, 사초수량 및 품질에 미치는 영향. 한초지. 12(2):111-122.

7. 송태화, 한옥규, 윤성근, 박태일, 서재환, 김경훈, 박기훈. 2009. 사료맥류의 생육단계별 수량 및 품질 변화. 초지조사료지 29(2):129-136.

8. 신만균, Hirosi Kurihara. 1995. 보리 파종기에 따 른 유효분얼의 발생과 수량. 한국작물학회지. 40 (4):460-472.

9. 신정남, 김병호. 1995. 봄 재배 연맥의 생육시기 별 건물수량 및 화학조성분. 한초지. 15(1):61-66. 
10. 연규복, 이춘우, 장영희, 이석순, 박연규. 1991. 총체용 맥류의 사료 생산성 및 사료적 가치. 한 국작물학회지. 36(6):496-500.

11. 이춘우, 구본철, 윤의병. 2000. 보리 춘파 재배시 파종기에 따른 생육단계별 소요일수와 적산온도 및 수량 관련 특성 변화. 한작지 45(6):366-369.

12. 조재영(저자대표). 1987. 전작(사정). 향문사. pp. 56-57.

13. 주정일, 이정준, 박기훈, 이희봉. 2009. 중부지역 에서 총체맥류의 예취시기별 사료가치 변화. 초 지조사료지. 29(3):187-196.

14. 채재석, 강재철, 구영서, 황종규. 1973. 추파성 과 맥의 춘파에 관한 연구. - 추파성 과맥의 파종기 별 출수반응. 한국작물학회지. 14:79-86.

15. 하용웅. $2000 \mathrm{a}$. 보리. 거목문화사. pp. 76-80.

16. 하용웅. 2000b. 보리. 거목문화사. pp. 81-82.
17. 하용웅. 2000c. 보리. 거목문화사. pp. 76-80, 242-243.

18. AOAC. 1995. Official methods of analysis. Association \& Official Analytical Chemists. Washington. DC.

19. Goering, H.K. and P.J. Van Soest. 1970. Forage fiber analysis. Agric. Handbook. No. 397. U.S. USDA. Washington DC.

20. Holland, C., W. Kezar, W.P. Kautz, E.J. Lazowski, W.C. Mahanna and R. Reinhart. 1990. The pioneer forage manual; A nutritional guide. Pioneer. Hi-Bred International, Inc., pp. 1-55.

(접수일: 2010년 4월 27일, 수정일 1차: 2010년 5월 12일, 수정일 2차: 2010년 5월 20일, 게재확정일: 2010년 7월 26일) 